\title{
Measuring Lean Culture: Designing a Research Instrument
}

\author{
A.A. Osman ${ }^{1,}$, , N. Nordin ${ }^{1}$, and M.F. Abd. Rahman ${ }^{2}$ \\ ${ }^{1}$ School of Technology Management and Logistics, Universiti Utara Malaysia, 06010 Kedah, Malaysia. \\ 2Organizational Excellence Department, Malaysia Productivity Corporation, 46200 Selangor, Malaysia.
}

ABSTRACT - Transformation from conventional manufacturing system to lean manufacturing system has enabled many manufacturing companies to reduce waste and ultimately achieve operational excellence. Unfortunately, there were also many reported cases where manufacturers failed to sustain the transformation until they achieve the ultimate result. Converting organization's culture into the lean culture is often claimed as one of the mechanisms to sustain lean transformation in manufacturing organizations. Thus, measuring to what level lean manufacturers have converted their organization's culture relative to lean culture characteristics is critical. Selfadministered questionnaire is a practical research instrument to measure the level of lean culture in multiple manufacturing organizations that are located in far-reaching geographical as it saves time, money and effort. In this paper, 36 questionnaire items for measuring lean culture has been designed. These items can be used as parameters for predicting sustainability of lean transformation using statistical analysis such as linear regression or structural equation modelling.

\section{ARTICLE HISTORY}

Revised: $20^{\text {th }}$ January 2021

Accepted: $21^{\text {st }}$ January 2021

\section{KEYWORDS}

Lean culture

Lean social pillar

Soft lean practices

Human-related lean

Measurement items

\section{INTRODUCTION}

Lean Manufacturing (LM) is an operational excellence strategy originated from Toyota Motor Company (TMC) with the aim to eliminate waste. Wastes in operational context can be classified into eight types, known as DOWNTIME (i.e. Defects, Overproduction, Waiting times, Non-utilized talents, Transportations, Inventories, Motions, and Excess processing). TMC success in overcoming 1973 global oil crisis through waste elimination had inspired many manufacturing organizations across the world to convert from conventional manufacturing system to LM system (Shah \& Ward, 2007). This manufacturing system conversion is shortly addressed as 'Lean Transformation' (Osman, Othman, \& Abdul Rahim, 2020; Roth, 2011). Unfortunately, most organizations that engaged in Lean Transformation experienced difficulties and challenges to achieve a sustainable success (Bhasin \& Burcher, 2006; Mohd Yusof \& Aoki, 2016; Pentlicki, 2014). Rationally, no organisation would adopt a new strategy that will eventually fail.

In response to this issue, many lean scholars had studied successfully sustained lean organizations to identify what are the determinants that contribute to Lean Transformation sustainability (Hines, Found, Griffiths, \& Harrison, 2011; Hogan, 2009; Marchwinski, 2014; Sisson \& Elshennawy, 2015; Testani \& Ramakrishnan, 2010). One of the prominent determinants identified was the shift from ordinary organization's culture to lean organization's culture (i.e. Lean Culture). Nevertheless, these studies were conducted through interviews and observations that only described Lean Culture using subjective measures. Hence, it is still unknown to what level successful lean organizations had shifted their organization's culture consistent to Lean Culture and to what extent the formation of Lean Culture in the organizations influence the sustainability of Lean Transformation. A practical research instrument commonly used to objectively measure a latent variable (concept) such as Lean Culture is self-administered questionnaire (SAQ) as it saves researcher's time, money and effort in data collection.

Although there were few prior studies measuring Lean Culture using objective measures, the research instrument used was either too long or too simple. For instance, Jenei, Toarniczky, Losonci, and Imre (2015) measured Lean Culture with 61 SAQ items, under 12 dimensions. On the other hand, Welo and Ringen (2015) measured Lean Culture with only 2 SAQ items. Instrument that is too long may cause respondents to provide superficial answers and will receive low response rate (De Vaus, 2002; Fowler, 2014). Meanwhile, instruments with very few items are unlikely to provide adequate measures and full meaning of the variable of interest i.e. lack of content validity (Hayduk \& Littvay, 2012; Isaac \& Michael, 1995). In that sense, it is important to consider the balance between the length of the questionnaire and its content validity in designing a research instrument for measuring Lean Culture.

Moreover, existing research instruments were lack of theoretical foundation. As an example, Urban (2015) developed 20 SAQ items, divided into 5 dimensions to measure Lean Culture. However, he did not provide clear conceptual definitions for each dimension. One of the rules of correspondence in SAQ design is to conceptually define every single latent variable so that discriminant validity is assured (Boateng, Neilands, Frongillo, Melgar-Quiñonez, \& Young, 2018; Carpenter, 2018; Neuman, 2014). Another example, Pedersen-Rise and Haddud (2016) designed 20 SAQ items in a single dimension. According to measurement theories, too many items in a single dimension may cause convergent validity issue (Boateng et al., 2018; Carpenter, 2018; Neuman, 2014). In fact, Pedersen-Rise and Haddud (2016) did not test their instrument to prove that it passed convergent validity assessment. Therefore, the main objective of this article is to design 
a practical research instrument (i.e. SAQ) based on solid theoretical foundations that can objectively measure Lean Culture in manufacturing organizations.

\section{APPLICATIONS OF SELF=ADMINISTERED QUESTIONNAIRE AS A RESEARCH INSTRUMENT}

Self-administered questionnaire (SAQ) refers to a questionnaire that has been designed specifically to be completed by a respondent without intervention of the researchers to aid respondents in answering questions inquired (Lavrakas, 2008). Hence, the SAQ employment can avoid bias. The use of SAQ as a research instrument is common and practical in studies aim to measure the level of an abstract concept (latent variable) such as human behavior, value and practices (Cooper \& Schindler, 2014). Lean Culture can be considered as an abstract concept that may include organisation members' beliefs, values, behaviours and routines to eliminate waste and continuously improve. Therefore, SAQ is an appropriate research instrument for measuring Lean Culture. Since this review piece focused on the application of SAQ as the research instrument to measure Lean Culture, the word 'instrument' and 'SAQ' are interchangeably used throughout this paper.

Generally, scientific research relies on two types of data; 1. quantitative and 2. qualitative (Creswell \& Creswell, 2018; Neuman, 2014). Quantitative data is data that represent some phenomenon, behavior or perception by assigning numbers in different amount or degree along a continuum from less to more. SAQ is the only research instrument that can translate abstract concepts (latent variables) into measurable variables (parameters that can be quantified) and produce quantitative data (Cooper \& Schindler, 2014; Fraenkel, Wallen, \& Hyun, 2012). On the contrary, qualitative data refers to non-numerical data such as texts, images or quotes focused on stories and expressive descriptions that require researchers to interpret real meanings and suggest new understanding (Saunders, Lewis, \& Thornhill, 2016; Zikmund, Babin, Carr, \& Griffin, 2009). On that account, quantitative data generates objective measures, while qualitative data contributes subjective measures. Since most previous studies that examined the effect of Lean Culture on Lean Transformation used qualitative data (Osman, Che Mamat, \& Mat Ali, 2020), there is a need to assess the same effect using quantitative data to generalize the findings on a bigger scale.

Albeit no type of data is actually superior to the other (Fraenkel et al., 2012), quantitative data do have several advantages over qualitative data. Firstly, output from quantitative data can be generalized more widely, while findings from qualitative data are not meant to be generalized (Zikmund et al., 2009). In addition, it produces hard evidence rather than subjective interpretations based on researchers' judgement that are susceptible to human errors and bias (Cooper \& Schindler, 2014). Since quantitative data is captured in numbers, it allows researchers to apply statistical analysis in making statements about the data. Statistical analysis enables researchers to extract important information, make predictions and establish facts from research data (Fowler, 2014).

SAQ also allows researcher to gather data with less time, cost and effort. Given the advantage of SAQ that can be distributed through postal service and e-mails, one researcher is enough to administer data collection covering a broad geographical area (Neuman, 2014). Besides that, researchers have better chance to reach target respondents that might be hard to access. Target respondents, such as major corporate executives are difficult to reach in person as security personnel, secretaries, or personal assistants limit the access. Fortunately, with SAQ researchers still can access these restrictive respondents through mails or online survey platforms (Cooper \& Schindler, 2014). Moreover, SAQ provides more anonymity to the subjects (respondents) under study compare to archival and experimental studies. SAQ also has lower risk of ethical breach, since it does not require researchers to directly engage with the subject of the study to collect the data (Creswell \& Creswell, 2018).

\section{SAQ DEVELOPMENT PROCEDURES}

Basically, design and development of a self-administered questionnaire (SAQ) involves 2 major phases namely; 1. item development and 2. instrument testing (Boateng et al., 2018; Carpenter, 2018; DeVellis, 2016). Nevertheless, this review piece only covered the first phase, since the second phase is outside the scope of this paper and will be considered for future research opportunity. In this paper, authors followed 5 steps of item development based on best practices advocated by Boateng et al. (Boateng et al., 2018) (see Figure 1).
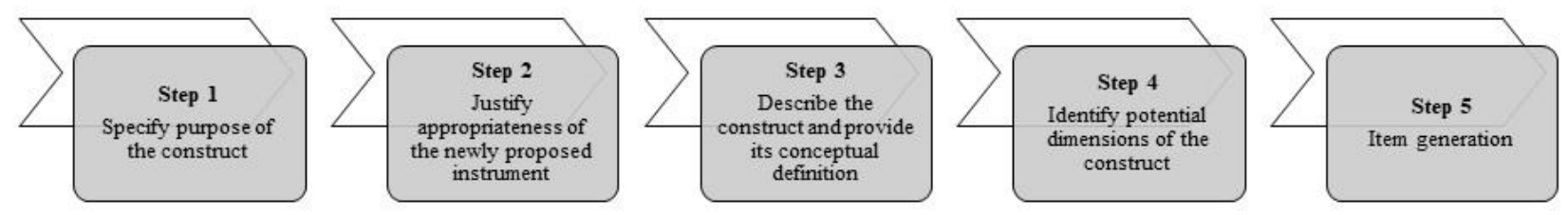

Figure 1. Five steps of item development.

\section{Step 1: Specify Purpose of the Construct}

Firstly, the purpose of developing items to measure a construct namely Lean Culture was specified. A construct refers to a concept, attribute or unobserved behavior that is the target of the study (Boateng et al., 2018). In some other context it is also known as latent variables (Hair, Hult, Ringle, \& Sarstedt, 2017) or a domain (Churchill, 1979; DeVellis, 2016). 
As most previous studies that investigate the influence of Lean Culture on sustainability of Lean Transformation were qualitative in nature (Osman, Che Mamat, et al., 2020), Lean Manufacturing body of knowledge is short of quantitative evidence regarding this topic. The absence of an appropriate research instrument for measuring Lean Culture makes researcher's effort to fill this gap more complicated and ardeous. Hence, there is a need to design and develop a valid and reliable research instrument (i.e. SAQ) to measure Lean Culture.

\section{Step 2: Justify Appropriateness of the Newly Proposed Instrument}

Albeit there are some similar research instruments in existence, the SAQs are either too long (Jenei et al., 2015), too simple (Welo \& Ringen, 2015) and/or lack of theoretical foundations (Pedersen-Rise \& Haddud, 2016; Urban, 2015). Long questionnaires may receive low response rate and encourage superficial answers from target respondents (De Vaus, 2002; Fowler, 2014). On the other hand, a too simple SAQ with very few items is inadequate to measure the construct of interest (Hayduk \& Littvay, 2012; Isaac \& Michael, 1995). An instrument is claimed to pass 'content validity' requirement when it provides adequate coverage of the construct of interest that encompassed its full meaning (Cooper \& Schindler, 2014). Moreover, existing SAQs mostly were designed without considering measurement theories such as Rules of Correspondence, Classical Test Theory and Item Response Theory as foundations. The primary goal of following these theories is to generate functional items that fulfil construct validity requirements including; 1 . convergent validity and 2. discriminant validity (Boateng et al., 2018). Convergent validity means the overlap (correlation) between several different items that are intended to measure the same construct (Saunders et al., 2016). Meanwhile, discriminant validity refers to the degree of a construct is truly distinct from other constructs, in terms of how much it correlates with other constructs, as well as how much SAQ items exclusively represent a construct (Hair et al., 2017). Thus, the newly proposed SAQ is deemed to be different from existing SAQs as it accounted for the balance between the length of the questionnaire and its content validity necessity. The present SAQ also considers convergent and discriminant validity requirements.

\section{Step 3: Describe the Construct and Provide Conceptual Definitions}

In conjunction with content and construct validity requirements, it is critical to clearly describe Lean Culture and provide its conceptual definition. A well-defined construct will provide a working knowledge of the phenomenon under study, specify the boundaries of the construct, and ease the process of item generation and content validation (Boateng et al., 2018). Recent systematic literature review by Dorval, Jobin, and Benomar (2019) had compiled 13 different definitions of Lean Culture (see Appendix). Interestingly, current review found another 10 definitions as the following:

1. Sánchez and Pérez (2001): A culture that is characterized by the decentralization of responsibility to the production workers and the decrease of hierarchic levels in the company.

2. Jørgensen, Matthiesen, Nielsen, and Johansen (2007): A culture that is contingent on learning and knowledge sharing.

3. Czabke, Hansen, and Doolen (2008): A problem solving culture and is based on the concepts of continuous improvement and learning.

4. Murti (2009): The culture of eliminating waste and continuously improve.

5. Rentes, Araujo, and Rentes (2009): A complex process of cultural change which demands absolute commitment from leadership and a long term consistent vision.

6. Fricke (2010): A culture where employees are actively involved and allowed to practice the application of lean in frequent trainings and their every-day tasks.

7. Roth (2011): A culture consists of empowered workforce and people assume responsibility for quality.

8. Zarbo (2012): A culture where quality is based on the pillars of respect for and development of people who are responsible for the continuous improvement.

9. Dennis (2016): A culture comprises PDCA, standardization, visual management, teamwork, intensity, paradox, and doing more with less resources as a door path.

10. Iranmanesh, Zailani, Hyun, Ali, and Kim (2019): An organizational culture that refers to the employees' awareness of lean practices, combined with the real things that are done.

Based on all 23 definitions compiled from the literature, several different characteristics of Lean Culture were identified. For example, some definitions characterized Lean Culture as organization's culture with high employee involvement (Fricke, 2010; Höök, 2008; Syed Ahmad, 2013; Zarbo, 2012), while few others perceived it as a culture in which organization members are intensively utilizing lean tools and techniques (Dennis, 2016; Manos \& Vincent, 2012). There was also a view that described Lean Culture as an organizational culture with a great leadership commitment (Rentes et al., 2009). These diverging definitions were implying that Lean Culture is a complex construct which encompassed several dimensions that distinguish a lean organization from an ordinary organization. Such unique dimensions also characterize an 'ideal' organizational culture that facilitates manufacturing organizations' success in their lean journey. Therefore, this study conceptually defined Lean Culture as the ideal organizational (corporate) culture that foster the success and sustainability of lean transformation in manufacturing organizations. 


\section{Step 4: Identify Potential Dimensions of the Construct}

Based on definitions of Lean Culture compiled from prior studies, authors identified and derived potential dimensions that ingrained in the Lean Culture construct. Compilation of definitions in the previous section revealed that Lean Culture can be operationalized and measured with at least six dimensions including; 1. Employee Involvement, 2. Continuous Improvement and Learning, 3. Lean Elements, 4. Customer Focus, 5. Management Commitment and Leadership, and 6. Organizational Environment (see Table 1).

Table 1. Dimensions derived from Lean Culture definitions.

\begin{tabular}{|c|c|c|}
\hline No & Dimensions & Source \\
\hline 1. & Employee involvement & $\begin{array}{l}\text { 1. Sánchez and Pérez (2001), } \\
\text { 2. Höök (2008), } \\
\text { 3. Fricke (2010), } \\
\text { 4. Roth (2011), } \\
\text { 5. Zarbo (2012), } \\
\text { 6. Syed Ahmad (2013), } \\
\text { 7. Lotz and Roodt (2014), } \\
\text { 8. Charron, Harrington, and Wiggin (2014), } \\
\text { 9. Iranmanesh et al. (2019) }\end{array}$ \\
\hline 2. & Continuous improvement and learning & $\begin{array}{l}\text { 1. Jørgensen et al. (2007), } \\
\text { 2. Czabke et al. (2008), } \\
\text { 3. Bicheno and Holweg (2009), } \\
\text { 4. Murti (2009), } \\
\text { 5. Lotz and Roodt (2014), } \\
\text { 6. Novac and Mihalcea (2014), } \\
\text { 7. Ulhassan (2014), } \\
\text { 8. Gaudet and Bergeron (2016) }\end{array}$ \\
\hline 3. & $\begin{array}{l}\text { Lean elements } \\
\text { (i.e. lean practices, tools and techniques) }\end{array}$ & $\begin{array}{l}\text { 1. Manos and Vincent (2012), } \\
\text { 2. Schipper and Swets (2012), } \\
\text { 3. Dennis (2016), } \\
\text { 4. Alston (2017) }\end{array}$ \\
\hline 4. & Customer focus & $\begin{array}{l}\text { 1. } \text { Stenzel (2007) } \\
\text { 2. } \text { Höök (2008) }\end{array}$ \\
\hline 5. & Management commitment and leadership & 1. Rentes et al. (2009) \\
\hline 6. & Organizational environment & Salah and Sayed (2015) \\
\hline
\end{tabular}

Table 1 revealed that the most cited dimension was Employee Involvement, followed by Continuous Improvement and Learning, Lean Elements and Customer Focus. On the contrary, there was only one citation each for Management Commitment and Leadership as well as Organizational Environment dimensions. However, majority of these studies are non-empirical sources. In fact, among empirical studies that defined Lean Culture, only Iranmanesh et al. (2019) operationalized it into a measurable construct. Nevertheless, Iranmanesh et al. (2019) only measured Lean Culture as a unidimensional construct. On the other hand, other empirical studies such as Urban (2015) measured Lean Culture based on five dimensions. A truly abstract construct should consist of at least three dimensions to capture the true essence of the concept and to ensure content validity (Carpenter, 2018). Authors believed that Lean Culture is a truly abstract construct because there is no consensus definition to formally describe it. In fact, recent systematic review of 1,066 publications in Lean Management area also concluded that the concept of Lean Culture is remained ambigous (Dorval et al., 2019). Hence, Lean Culture should be measured as a multidimensional construct in line with Carpenter (2018) notion. As abstractness increases, researchers can expect the construct to be consisted of more than one dimension.

In addition, Carpenter (2018) advised researchers to conduct literature review beyond the lens of the construct label (name). Researchers were encouraged to search for literature and review possible dimensions of the construct and justify their relation with the overarching construct. A literature review is necessary to map the dimensional structure of the construct as researchers need to craft items that reflect their theoretical understanding of each dimension. Following this advise, authors widen the search terms beyond 'lean culture' and retrieved some more empirical papers on culturalrelated constructs in Lean Manufacturing studies. As a result, studies on 'lean soft practices' (Che Mamat, Md Deros, Ab Rahman, Omar, \& Abdullah, 2015), 'social pillars of lean' (McMackin \& Flood, 2019), and 'human factors of lean' (Nagaraj \& Jeyapaul, 2020) were retrieved and reviewed to better understand possible dimensions associated with Lean Culture. Conceptual definitions and relevant empirical items that reflect each dimension were thoroughly identified. All identified dimensions and their sources were charted as in Table 2. 
Table 2. Dimensions derived from empirical studies related to Lean Culture.

\begin{tabular}{|c|c|c|c|}
\hline No & Dimensions & Sources & $\begin{array}{l}\text { Total } \\
\text { Citations }\end{array}$ \\
\hline 1. & Leadership / management commitment & $2,3,5,12,13.15,16,17,21,22,24,25$ & 12 \\
\hline 2. & $\begin{array}{l}\text { Employee involvement (including respect for } \\
\text { people, people treatment and people integration) }\end{array}$ & $5,8,11,16,20,21,22,23,24,26$ & 10 \\
\hline 3. & $\begin{array}{l}\text { Training employees (including learning, } \\
\text { knowledge and skill enhancement) }\end{array}$ & $2,3,6,10,12,14,16,17,22,24$ & 10 \\
\hline 4. & Continuous improvement & $2,4,11,14,17,22,23,26$ & 8 \\
\hline 5. & Supplier partnership & $2,11,12,13,14,1,21,25$ & 8 \\
\hline 6. & Customer involvement & $2,11,13,14,17,21,25$ & 7 \\
\hline 7. & Human Resource Management & $7,9,13,18,19,25,26$ & 7 \\
\hline 8. & Communication & $1,3,11,16,25,26$ & 6 \\
\hline 9. & Problem solving & $2,6,12,15,17$ & 5 \\
\hline 10. & Teamwork & $10,16,22,24,26$ & 5 \\
\hline 11. & $\begin{array}{l}\text { Lean elements (including value stream, visual } \\
\text { control, and standardized work) }\end{array}$ & $5,7,11,20,25$ & 5 \\
\hline 12. & Employee suggestions & $4,10,14,15$ & 4 \\
\hline 13. & Employee empowerment & $4,10,22$ & 3 \\
\hline 14. & Long-term thinking & $3,4,5$ & 3 \\
\hline 15. & Recognition \& reward system & 3,4 & 2 \\
\hline 16. & Multi-functional employees & 12,22 & 2 \\
\hline 17. & Humane orientation & 2,22 & 2 \\
\hline 18. & Organizational environment & 3 & 1 \\
\hline 19. & Innovation & 3 & 1 \\
\hline 20. & Coaching & 15 & 1 \\
\hline
\end{tabular}

Sources: 1. García, Maldonado, Alvarado, and Rivera (2014), 2. Bortolotti, Boscari, and Danese (2015), 3. Jenei et al. (2015), 4. Schröders and Cruz-Machado (2015), 5. Urban (2015), 6. Welo and Ringen (2015), 7. Basu, Ghosh, and Dan (2018), 8. El Khalil (2018), 9. Ghobakhloo, Fathi, Fontes, and Ng (2018), 10. Taherimashhadi and Ribas (2018), 11. van Assen (2018), 12. Abdallah, Ed Dahiyat, and Matsui (2019), 13. Al Najem, Garza-Reyes, and El Melegy (2019), 14. Antomarioni, Ciarapica, De Sanctis, and Ordieres-Meré (2019), 15. Beraldin, Danese, and Romano (2019), 16. Costa et al. (2019), 17. Gaiardelli, Resta, and Dotti (2019), 18. Iranmanesh et al. (2019), 19. Khaw, Zailani, Iranmanesh, and Heidari (2019), 20. Maware and Adetunji (2019), 21. Sahoo (2019), 22. Hernandez-Matias, Ocampo, Hidalgo, and Vizan (2020), 23. Loyd, Harrris, Gholston, and Berkowitz (2020), 24. Möldner, Garza-Reyes, and Kumar (2020), 25. Shafiq and Soratana (2020), 26. V. Wickramasinghe and Wickramasinghe (2020)

Referring to Table 2, 20 dimensions of Lean Culture were derived from 26 empirical studies. All six dimensions (i.e. Employee Involvement, Continuous Improvement and Learning, Lean Elements, Customer Focus, Management Commitment and Leadership, and Organisational Environment) identified based on Lean Culture definitions were also appeared among these 20 dimensions. The top 5 Lean Culture dimensions with most citations were including; 1. Management Commitment and Leadership, 2. Employee Involvement, 3. Training Employees, 4. Continuous Improvement and 5. Supplier Partnership. On the contrary, 1. Humane Orientation, 2. Organizational Environment, 3. Innovation, 4. Value Stream, and 5. Coaching, were the bottom 5 with the least citations.

However, the frequency of study (number of citations) was not the primary criteria for authors to select any particular dimension. The main consideration for selecting dimensions to operationalize and measure Lean Culture construct was based on their uniqueness. One dimension should not have overlapping meaning to another dimension nor has the same items. This was to ensure that there would be no discriminant validity issue between the proposed dimensions later. For instance, some studies classified Problem Solving, Continuous Improvement, Employees Training and Employee Suggestion as separate dimensions (Antomarioni et al., 2019; Beraldin et al., 2019; Bortolotti et al., 2015; Welo \& Ringen, 2015). On the other hand, some other studies included problem solving, continuous improvement, employees training and employee suggestion as correlated items for measuring Employee Involvement (Costa et al., 2019; Hernandez-Matias et al., 2020) or Human Resource Management (Al Najem et al., 2019; Ghobakhloo et al., 2018; Iranmanesh et al., 2019) dimensions. According to Carpenter (2018), it is common to find conceptual redundancy even though dimensions vary in labels (names) within and across disciplines.

Finally, after a rigorous content analysis was made, comparing and delineating each dimension, authors decided to propose five dimensions of Lean Culture that deemed unique and distinctive to one another. The five Lean Culture dimensions are as the following:

1. Organizational Environment: Reflects a non-blaming and process-driven working environment that inspire mutual trust and respect for people among organization members in a lean organization (Degirmenci, Yegul, Erenay, Striepe, \& Yavuz, 2013; Iranmanesh et al., 2019).

2. Effective Communication: The extent to which important information on lean transformation journey is effectively transferred between organization members. 
3. Teamwork: The extent to which lean transformation and problem resolution activities are handled in teams.

4. Problem Solving: The extent of problem resolution activities are carried out based on lean philosophy.

5. Innovation: Represents a work culture that welcome new ideas and allowed innovations to take place through experimentation and risk-taking.

\section{Step 5: Item Generation}

Boateng et al. (2018) suggested two (2) approches to appropriately generate SAQ items namely; 1 . deductive and 2. inductive. The deductive approach is based on the description of the relevant constructs and the identification of items. This can be done through literature review and assessment of existing instrument and items of that construct. On the other hand, inductive approach involves the generation of items from the responses of individuals obtained through focus group discussion and interviews. Authors had used deductive approach to generate items for measuring Lean Culture since it is more practical for studies involving manufacturing sector. It is well-known that manufacturing is one of the hectic economic sector in Malaysia. On that account, conducting focus group discussion or interview sessions with managerial level personnel from manufacturing sector can be very time consuming, considering their hectic schedule. Hence, items in the present SAQ are generated from literature review and adaptation from several existing instruments.

In order to comply with both content and convergent validity requirements, authors carefully assigned number of items per dimension. Although existing instrument as in Pedersen-Rise and Haddud (2016) comprised 20 items in a single dimension, there was no evident of any validity assessment reported by the researchers. It is true that the specification of an asbtract concept can result in an indefinite number of items. Yet, it is important to include only the optimal sample of items and dimensions to empirically represent its abstractness (Carpenter, 2018). The requirement for achieving content validity is the minimum of three (3) items per dimension (Carpenter, 2018; Hair, Black, Babin, \& Anderson, 2019). On the other hand, to pass convergent validity, a construct or dimension should not consist too many items. Although there is no clear cut on the maximum number of items should be considered to fulfil convergent validity, researchers should keep in mind that average variance extracted (AVE) value used to indicate convergent validity will decrease as the number of items increase (see Equation 1 and 2).

$$
\mathrm{AVE}=\left(\frac{\sum_{i=1}^{M} l_{i}^{2}}{M}\right)
$$

where,

$l=$ factor loadings

$\mathrm{M}=$ number of items

$$
\mathrm{AVE}=\frac{\text { sum } \text { of the squared factor loadings }}{\text { number of items }}
$$

Source: Hair et al. (2017)

Equation 1 and 2 showed that AVE is inversely proportional with number of items. The minimum acceptable value for AVE is 0.50 (Hair et al., 2017). On that account, the denominator (i.e. number of items per dimension) should be controlled as the numerator (items' factor loadings) cannot be easily estimated. Factor loading values is totally empirical, based on how respondents perceive each item is correlated to one another. Hence, the present SAQ is designed with six (6) to eight (8) items per dimension, resulting in 36 items in total (see Table 3).

\begin{tabular}{|c|c|c|c|}
\hline No & Dimensions & Items & Sources \\
\hline 1. & $\begin{array}{l}\text { Organizational } \\
\text { Environment }\end{array}$ & $\begin{array}{l}\text { 1. Nobody hides faults; spotted errors are treated as opportunity to } \\
\text { improve } \\
\text { 2. Employees at all positions report errors/ faults without fear of } \\
\text { blame } \\
\text { 3. When error happens, manufacturing process(s) is to be } \\
\text { improved (rather than finding who to blame) } \\
\text { 4. Priority is given to gradual improvements rather than drastic } \\
\text { changes in manufacturing processes } \\
\text { 5. Continuous searching for possible improvements is part of the } \\
\text { daily routine } \\
\text { 6. All functional departments/ units demonstrate a high } \\
\text { commitment on eliminating waste } \\
\text { 7. There is a stable inter-functional cooperation to eliminate waste }\end{array}$ & $\begin{array}{l}\text { Jenei et al. (2015), } \\
\text { Pedersen-Rise and } \\
\text { Haddud (2016) }\end{array}$ \\
\hline
\end{tabular}

Table 3. Proposed dimensions and items to measure Lean Culture. 
2. Effective Communications

3. Teamwork

\section{Problem Solving}

\section{Innovation}

1. There are effective two-way communications in this plant; topdown and bottom-up communications work in parallel

2. There are good communications between different functional departments in conducting LEAN transformation projects

3. Organizational position is not a barrier to communicate on process improvement

4. Employees at all positions are constantly provided with information of LEAN strategic nature

(e.g. transformation plans, objectives, vision, etc.)

5. Plant management clearly communicated the need(s) for pursuing LEAN transformation

6. Plant management clearly communicated both individual and work teams responsibilities for reducing waste

7. Plant management clearly communicated regular updates on relevant operational status (e.g. quality, delivery, safety problems, and achievements)

8. Our plant emphasises on communicating in a visual way (e.g. notice boards, photos, charts, signal lights, etc.)

1. Formation of production work teams is the first priority in LEAN transformation

2. Working in teams means everyone is willing to help out and hold each other accountable

3. Team goals dominate individual goals

4. Decisions are made and problems are solved in teams rather than by individuals

5. There is an effort to get all team members' opinions and ideas before making a decision

6. Considering inputs from many functional areas in decisionmaking processes is a common practice in this plant

7. Production work teams are empowered to decide on most issues happening in their own work areas (e.g. problem resolutions, process improvement, new working methods, etc.)

1. Production employees dare to face conflicts instead of hiding problems

2. Identifying root causes rather than applying any quick fix as temporary solutions

3. Considering various alternatives (potential solutions) to seek consensus

4. Using systematic format (e.g. PDCA cycle, DMAIC sequence, 5 Whys, etc.)

5. Rely on scientific methods rather than simple guess for diagnosing production problems

6. Discussion / debate on conflicting opinions to find the best solution is a common practice

7. Solutions are long thought, but implemented immediately (rapid implementation)

8. Solutions are implemented based on facts and data, rather than assumptions

1. Employees at all positions are open to new ideas that may make work easier or better

2. Employees at all positions are really interested in new ideas to eliminate waste

3. Production work teams are continuously experimenting with the new ways of working to improve work process

4. Production work teams are continuously experimenting with the new ways of working to eliminate waste

5. Production work teams are permitted to undertake calculated risk while experimenting with the new ways of working

6. Fail experimentations are not penalized, production work teams are encouraged to learn from mistakes instead
Jayaraman, Teo, and Keng (2012),

G. L. D.

Wickramasinghe and

Wickramasinghe (2017)

Galeazzo, Furlan, and Vinelli (2017), Jenei et al. (2015)

Jenei et al. (2015) and Pedersen-Rise and Haddud (2016)

Jenei et al. (2015) and Hui, Sengphet, and Phong (2019)

Meaningful measurement occurs when the body of questions (items) successfully achieves the intended representation of the abstract construct. Therefore, three (3) items per construct (dimension) are deemed sufficient to serve that purpose 
(Carpenter, 2018; Hair et al., 2019). Yet, Boateng et al. (2018) asserted that the initial number of items generated by researchers should be at least twice the number of desired finalize items to provide requisite margin to select an optimum combination of items. Thus, authors believed that six (6) to eight (8) items per dimension which are twice the number of minimum items required to deliver meaningful measurement are relevant. The number of scales used to indicate the agreement of respondents to each item (statement), is 7-points perceptual scale with extreme end-points $(1=$ strongly disagree, 7 = strongly agree) following recommendation of Boateng et al. (2018) and Weijters, Cabooter, and Schillewaert (2010).

\section{CONCLUSION}

The purpose of this conceptual paper was to propose a research instrument (self-administered questionnaire) that can be used for assessing Lean Culture in manufacturing organizations. This was done according to five (5) steps of SAQ development procedures outlined by Boateng et al. (2018). As a result, authors conceptually defined Lean Culture as an ideal organizational (corporate) culture that foster the success and sustainability of lean transformation in manufacturing organizations and proposed five dimensions with 36 items to measure the concept. Five dimensions of Lean Culture are including; 1. Organizational Environment, 2. Effective Communication, 3. Teamwork, 4. Problem Solving, and 5. Innovation. These five dimensions represent characteristics that distinguish a lean organization from an ordinary organization.

The proposed dimensions and items in this paper however, is still a work in progress as is yet to be validated by panel of experts and subsequently tested in the real manufacturing setting (empirical testing). Experts validation will help in confirming instrument content validity for further refinement. In addition, empirical test by the means of statistical analysis such as factor analysis (exploratory or confirmatory) or confirmatory composite analysis will yield construct validity and reliability of Lean Culture. This SAQ also serves as a breakthrough and stepping stone for future studies that aim to statistically predict the effect of Lean Culture on other criterion variables besides sustainability of Lean Transformation in manufacturing organizations.

\section{ACKNOWLEDGEMENT}

The authors acknowledge lean consultants from Malaysia Productivity Corporation (Mr. Josffa Ismail and Ms. Norhasimah Ibrahim) and Lean Management Academy Sdn. Bhd. (Mr. Muhar Murad). Special thanks for their expert opinions and precious insights regarding this topic.

\section{REFERENCES}

Abdallah, A. B., Ed Dahiyat, S., \& Matsui, Y. (2019). Lean management and innovation performance: Evidence from international manufacturing companies. Management Research Review, 42(2), 239-262. doi:10.1108/MRR-10-2017-0363

Al Najem, M., Garza-Reyes, J. A., \& El Melegy, A. (2019). Measuring the lean readiness of Kuwaiti manufacturing industries. International Journal of Business Performance Management, 20(1), 70-92. doi:10.1504/ijbpm.2019.096467

Alston, F. (2017). Lean Implementation Applications and Hidden Costs. Boca Raton, FL: CRC Press.

Antomarioni, S., Ciarapica, F. E., De Sanctis, I., \& Ordieres-Meré, J. (2019). The influence of cultural dimensions on lean projects success and barriers. International Journal of Management and Decision Making, 18(2), 151-182. doi:10.1504/ijmdm.2019.098644

Basu, P., Ghosh, I., \& Dan, P. K. (2018). Using structural equation modelling to integrate human resources with internal practices for lean manufacturing implementation. Management Science Letters, 8(1), 51-68. doi:10.5267/j.msl.2017.10.001

Beraldin, A. R., Danese, P., \& Romano, P. (2019). An investigation of the relationship between lean and well-being based on the job demands-resources model. International Journal of Operations \& Production Management, 39(12), 1295-1322. doi:10.1108/IJOPM-05-2019-0377

Bhasin, S., \& Burcher, P. (2006). Lean viewed as a philosophy. Journal of Manufacturing Technology Management, 17(1), 56-72.

Bicheno, J., \& Holweg, M. (2009). The lean toolbox: The essential guide to lean transformation (4th Ed.). Buckingham, United Kingdom: PICSIE Books.

Boateng, G. O., Neilands, T. B., Frongillo, E. A., Melgar-Quiñonez, H. R., \& Young, S. L. (2018). Best practices for developing and validating scales for health, social, and behavioral research: A primer. Frontiers in public health, 6(149), 1-18.

Bortolotti, T., Boscari, S., \& Danese, P. (2015). Successful lean implementation: Organizational culture and soft lean practices. International Journal of Production Economics, 160, 182-201. doi:10.1016/j.ijpe.2014.10.013

Carpenter, S. (2018). Ten steps in scale development and reporting: A guide for researchers. Communication Methods and Measures, 12(1), 25-44.

Charron, R., Harrington, H. J., \& Wiggin, H. (2014). The Lean Management Systems Handbook (1st ed.). Boca Raton, FL: CRC Press.

Che Mamat, R., Md Deros, B., Ab Rahman, M. N., Omar, M. K., \& Abdullah, S. (2015). Soft lean practices for successful lean production system implementation in Malaysia automotive SMEs. Jurnal Teknologi, 77(27), 141-150. doi:10.11113/jt.v77.6910

Churchill, G. A. (1979). A paradigm for developing better measures of marketing constructs. Journal of Marketing Research, 16(1), 64-73. doi: $10.2307 / 3150876$

Cooper, D. R., \& Schindler, P. S. (2014). Business research methods (12th ed.). New York, NY: McGraw-Hill/Irwin. 
Costa, F., Lispi, L., Staudacher, A. P., Rossini, M., Kundu, K., \& Cifone, F. D. (2019). How to foster sustainable continuous improvement: A cause-effect relations map of lean soft practices. Operations Research Perspectives, 6, 100091. doi:10.1016/j.orp.2018.100091

Creswell, J. W., \& Creswell, J. D. (2018). Research design: Qualitative, quantitative and mixed methods approaches (5th ed.). Thousand Oaks, CA: SAGE Publications, Inc.

Czabke, J., Hansen, E. N., \& Doolen, T. L. (2008). A multisite field study of lean thinking in US and German secondary wood products manufacturers. Forest Products Journal, 58(9), 77.

De Vaus, D. (2002). Surveys in social research (5th ed.). New South Wales, Australia: Allen \& Unwin.

Degirmenci, T., Yegul, M. F., Erenay, F. S., Striepe, S., \& Yavuz, M. (2013). Potential of standardization and certification for successful lean implementations. Journal of Enterprise Transformation, 3(3), 211-232. doi:10.1080/19488289.2013.816809

Dennis, P. (2016). Lean production simplified: A plain-language guide to the world's most powerful production system (3rd ed.). Boca Raton, FL: CRC Press.

DeVellis, R. F. (2016). Scale development: Theory and Application (4th ed. Vol. 26). Thousand Oaks, CA: SAGE Publications, Inc.

Dorval, M., Jobin, M.-H., \& Benomar, N. (2019). Lean culture: A comprehensive systematic literature review. International Journal of Productivity and Performance Management, 68(5), 920-937. doi:10.1108/IJPPM-03-2018-0087

El Khalil, R. (2018). The mediating effect of lean management on the relationship between flexibility implementation and operational metrics in US automotive manufacturing plants. Journal of Manufacturing Technology Management, 29(8), 1376-1399. doi:10.1108/JMTM-04-2018-0108

Fowler, F. J. (2014). Survey research methods (5th ed.). Thousand Oaks, CA: SAGE Publications, Inc.

Fraenkel, J. R., Wallen, N. E., \& Hyun, H. H. (2012). How to design and evaluate research in education (8th ed.). New York, NY: McGraw-Hill Companies, Inc.

Fricke, C. F. (2010). Lean management: Awareness, implementation status, and need for implementation support in virginia's wood industry. (Master of Science in Wood Science and Forest Products), Virginia Polytechnic Institute and State University, Blacksburg, VA.

Gaiardelli, P., Resta, B., \& Dotti, S. (2019). Exploring the role of human factors in lean management. International Journal of Lean Six Sigma, 10(1), 339-366. doi:10.1108/IJLSS-08-2017-0094

Galeazzo, A., Furlan, A., \& Vinelli, A. (2017). The organizational infrastructure of continuous improvement - an empirical analysis. Operations Management Research, 10(1), 33-46. doi:10.1007/s12063-016-0112-1

García, J. L., Maldonado, A. A., Alvarado, A., \& Rivera, D. G. (2014). Human critical success factors for kaizen and its impacts in industrial performance. The International Journal of Advanced Manufacturing Technology, 70(9), 2187-2198. doi:10.1007/s00170-013-5445-4

Gaudet, J., \& Bergeron, F. (2016). Lean: it's not rocket science, it's work science. Retrieved from Ottowa, ON: https://ruor.uottawa.ca/handle/10393/35002

Ghobakhloo, M., Fathi, M., Fontes, D. B. M. M., \& Ng, T. C. (2018). Modeling lean manufacturing success. Journal of Modelling in Management, 13(4), 908-931. doi:10.1108/JM2-03-2017-0025

Hair, J. F., Black, W. C., Babin, B. J., \& Anderson, R. E. (2019). Multivariate data analysis (8th ed.). Hampshire, UK: Cengage Learning.

Hair, J. F., Hult, G. T. M., Ringle, C. M., \& Sarstedt, M. (2017). A primer on partial least squares structural equation modeling (PLSSEM) (2nd ed.). Thousand Oaks, CA: SAGE Publications Inc.

Hayduk, L. A., \& Littvay, L. (2012). Should researchers use single indicators, best indicators, or multiple indicators in structural equation models? BMC Medical Research Methodology, 12(1), 159. doi:10.1186/1471-2288-12-159

Hernandez-Matias, J. C., Ocampo, J. R., Hidalgo, A., \& Vizan, A. (2020). Lean manufacturing and operational performance: Interrelationships between human-related lean practices. Journal of Manufacturing Technology Management, 31(2), 217235. doi:10.1108/JMTM-04-2019-0140

Hines, P., Found, P. A., Griffiths, G., \& Harrison, R. (2011). Staying lean: Thriving, not just surviving (2nd ed.). New York, NY: Lean Enterprise Research Centre, Cardiff University.

Hogan, B. J. (2009, December 1st, 2016). Sustaining a lean culture. Manufacturing Engineering Magazine, 143, 71-76.

Höök, M. (2008). Lean culture in industrialized housing: A study of timber volume element prefabrication. (Doctorate in Structural Engineering), Luleå University of Technology, Luleå, Sweden.

Hui, L., Sengphet, P., \& Phong, B. L. (2019). How to foster innovative culture and capable champions for Chinese firms: An empirical research. Chinese Management Studies, 13(1), 51-69. doi:10.1108/CMS-05-2018-0502

Iranmanesh, M., Zailani, S., Hyun, S. S., Ali, M. H., \& Kim, K. (2019). Impact of lean manufacturing practices on firms' sustainable performance: Lean culture as a moderator. Sustainability, 11(4), 1112. doi:10.3390/su11041112

Isaac, S., \& Michael, W. B. (1995). Handbook in research and evaluation: A collection of principles, methods, and strategies useful in the planning, design, and evaluation of studies in education and the behavioral sciences (3rd ed.). San Diego, CA: EdITS Publishers.

Jayaraman, K., Teo, L. K., \& Keng, L. S. (2012). The perceptions and perspectives of Lean Six Sigma (LSS) practitioners: An empirical study in Malaysia. The TQM Journal, 24(5), 433-446. doi:10.1108/02656711211190873

Jenei, I., Toarniczky, A., Losonci, D., \& Imre, N. (2015). Lean organisational culture - development and testing of a measurement tool. European Journal of Cross-Cultural Competence and Management, 3(3-4), 257-278. doi:10.1504/ejccm.2015.071961

Jørgensen, F., Matthiesen, R., Nielsen, J., \& Johansen, J. (2007). Lean maturity, lean sustainability. In J. Olhager \& F. Persson (Eds.), Advances in Production Management Systems (pp. 371-378). Aalborg, Denmark: IFIP International Federation for Information Processing.

Khaw, S. M., Zailani, S., Iranmanesh, M., \& Heidari, S. (2019). Do lean manufacturing practices have negative impact on job satisfaction? International Journal of Lean Six Sigma, 10(1), 257-274. doi:10.1108/IJLSS-11-2016-0072

Lavrakas, P. (2008). Self-administered questionnaire. In P. Lavrakas (Ed.), Encyclopedia of survey research methods (Vol. 1 \& 2). Thousand Oaks, CA: SAGE Publications, Inc.

Lotz, G., \& Roodt, G. (2014). Values and behaviours that the Lean production philosophy supports. Paper presented at the Proceedings of the 31st Pan Pacific Conference, Osaka, JP. 
Loyd, N., Harrris, G., Gholston, S., \& Berkowitz, D. (2020). Development of a lean assessment tool and measuring the effect of culture from employee perception. Journal of Manufacturing Technology Management, xx(xx), xx-xx. doi:10.1108/JMTM-10-20190375

Manos, A., \& Vincent, C. (2012). The Lean Certification Handbook: A Guide to the Bronze Certification Body of Knowledge. Milwaukee, WI: Quality Press.

Marchwinski, C. (2014). Sustain your lean business system with a "Golden Triangle". Knowledge Center. Retrieved from http://www.lean.org/common/display/?o=2592

Maware, C., \& Adetunji, O. (2019). The moderating effect of industry clockspeed on Lean Manufacturing implementation in Zimbabwe. The TQM Journal, 32(2), 288-304. doi:10.1108/TQM-03-2019-0080

McMackin, J., \& Flood, P. (2019). A theoretical framework for the social pillar of lean. Journal of Organizational Effectiveness: People and Performance, 6(1), 39-55. doi:10.1108/JOEPP-06-2018-0039

Mohd Yusof, S. r., \& Aoki, K. (2016, March 8-10). Proposed lean sustained factors. Paper presented at the The 6th International Conference on Industrial Engineering and Operations Management (IEOM 2016), Kuala Lumpur, Malaysia.

Möldner, A. K., Garza-Reyes, J. A., \& Kumar, V. (2020). Exploring lean manufacturing practices' influence on process innovation performance. Journal of Business Research, 106, 233-249. doi:10.1016/j.jbusres.2018.09.002

Murti, Y. (2009). Sustaining lean in New Zealand manufacturing organisations. (Master of Technology in Engineering and Industrial Management), Massey University, Palmerston North, AC.

Nagaraj, T. S., \& Jeyapaul, R. (2020). An empirical investigation on association between human factors, ergonomics and lean manufacturing. Production Planning \& Control, 1-15. doi:10.1080/09537287.2020.1810815

Neuman, L. (2014). Social research methods: Qualitative and quantitative approaches (7th ed.). Harlow, United Kingdom: Pearson Education Ltd.

Novac, C., \& Mihalcea, A. (2014). The relationship between leadership, organizational culture and managerial culture through Lean strategy in a multinational company. In C. Bratianu, A. Zbuchea, F. Pinzaru, \& E. M. Vatamanescu (Eds.), Strategica: Management, Finance, and Ethics (pp. 349-369). Bucharest, Romania: Tritonic Publishing House.

Osman, A. A., Che Mamat, R., \& Mat Ali, M. (2020). Lean transformational sustainability models: A critical review. Advances in Business Research International Journal, 6(2), 1-18. doi:10.24191/abrij.v6i2.10581

Osman, A. A., Othman, A. A., \& Abdul Rahim, M. K. I. (2020). Defining and developing measures of lean sustainability for manufacturing sector. IOP Conference Series: Materials Science and Engineering, 864, 012111. doi:10.1088/1757899x/864/1/012111

Pedersen-Rise, O., \& Haddud, A. (2016). Exploring lean culture challenges in a small family-owned manufacturing company: A case study from Norway. International Journal of Lean Enterprise Research, 2(1), 1-25. doi:10.1504/ijler.2016.078247

Pentlicki, J. H. (2014). Barriers and success strategies for sustainable lean manufacturing implementation: A qualitative case study. (Doctor of Management in Organizational Leadership), University of Phoenix, Phoenix, AZ.

Rentes, A. F., Araujo, C. A. C., \& Rentes, V. C. (2009). Best practice examples in sustaining improvements from Lean implementation. Paper presented at the Proceedings of the 2009 Industrial Engineering Research Conference (IeRC), Marriott Resort, Miami.

Roth, G. (2011). Sustaining lean transformation through growth and positive organizational change. Journal of Enterprise Transformation, 1(2), 119-146.

Sahoo, S. (2019). Lean manufacturing practices and performance: The role of social and technical factors. International Journal of Quality \& Reliability Management, 37(5), 732-754. doi:10.1108/IJQRM-03-2019-0099

Salah, S. A., \& Sayed, M. M. (2015). Improving the organizational lean culture by using Critical Lean Culture Criteria Model: Case study. Paper presented at the International Conference on Aerospace Sciences and Aviation Technology (ASAT), Military Technical College, Cairo.

Sánchez, A. M., \& Pérez, M. (2001). Lean indicators and manufacturing strategies. International Journal of Operations \& Production Management, 21(11), 1433-1452.

Saunders, M., Lewis, P., \& Thornhill, A. (2016). Research methods for business students (7th ed.). Harlow, United Kingdom: Pearson Education Ltd.

Schipper, T., \& Swets, M. (2012). Innovative Lean Development: How to Create, Implement and Maintain a Learning Culture using Fast Learning Cycles (1st ed.). Boca Raton, FL: CRC Press.

Schröders, T., \& Cruz-Machado, V. (2015). Sustainable lean implementation: An assessment tool. Paper presented at the Proceedings of the Ninth International Conference on Management Science and Engineering Management, Advances in Intelligent Systems and Computing, Berlin Heidelberg.

Shafiq, M., \& Soratana, K. (2020). Lean readiness assessment model - a tool for Humanitarian Organizations' social and economic sustainability. Journal of Humanitarian Logistics and Supply Chain Management, 10(2), 77-99. doi:10.1108/JHLSCM-012019-0002

Shah, R., \& Ward, P. T. (2007). Defining and developing measures of lean production. Journal of Operations Management, 25(4), 785-805.

Sisson, J., \& Elshennawy, A. (2015). Achieving success with lean. International Journal of Lean Six Sigma, 6(3), 263-280.

Stenzel, J. (2007). Lean Accounting: Best Practices for Sustainable Integration. Hoboke, NJ: John Wiley \& Sons.

Syed Ahmad, S. A. (2013). Culture and lean manufacturing: Towards a holistic framework. Australian Journal of Basic and Applied Sciences, 7(1), 334-338.

Taherimashhadi, M., \& Ribas, I. (2018). A model to align the organizational culture to lean. Journal of Industrial Engineering and Management, 11(2), 207-221. doi:10.3926/jiem.2511

Testani, M. V., \& Ramakrishnan, S. (2010). The role of leadership in sustaining a lean transformation. Paper presented at the Proceedings of the 2010 Industrial Engineering Research Conference (IeRC), Springfield, MO.

Ulhassan, W. (2014). Lean, team and psychosocial factors: A longitudinal investigation at a Swedish. (Doctor of Philosophy), Karolinska Institutet, Stockholm, Sweden.

Urban, W. (2015). The lean management maturity self-assessment tool based on organizational culture diagnosis. Procedia - Social and Behavioral Sciences, 213, 728-733. doi:10.1016/j.sbspro.2015.11.527

van Assen, M. F. (2018). The moderating effect of management behavior for Lean and process improvement. Operations Management Research, 11(1), 1-13. doi:10.1007/s12063-018-0129-8 
Weijters, B., Cabooter, E., \& Schillewaert, N. (2010). The effect of rating scale format on response styles: The number of response categories and response category labels. International Journal of Research in Marketing, 27(3), 236-247.

Welo, T., \& Ringen, G. (2015). Investigating lean development practices in SE companies: A comparative study between sectors. Procedia Computer Science, 44, 234-243. doi:10.1016/j.procs.2015.03.056

Wickramasinghe, G. L. D., \& Wickramasinghe, V. (2017). Implementation of lean production practices and manufacturing performance: The role of lean duration. Journal of Manufacturing Technology Management, 28(4), 531-550. doi:10.1108/JMTM-08-2016-0112

Wickramasinghe, V., \& Wickramasinghe, G. L. D. (2020). Effects of HRM practices, lean production practices and lean duration on performance. The International Journal of Human Resource Management, 31(11), 1467-1512. doi:10.1080/09585192.2017.1407954

Zarbo, R. J. (2012). Creating and sustaining a lean culture of continuous process improvement. American Journal of Clinical Pathology, $138(3), 321-326$.

Zikmund, W. G., Babin, B. J., Carr, J. C., \& Griffin, M. (2009). Business research methods (8th ed.). Cambridge, MA: Cengage Learning.

\section{APPENDIX}

Lean culture definitions taken from Dorval et al. (2019) work:

1. Stenzel (2007): Shared mindset that demands excellence in providing customer value.

2. Höök (2008): Shared assumptions that the common goal is increased long-term profit, achieved by decreased costs and waste, through a focus on customers and the people that create value.

3. Bicheno and Holweg (2009): All people, from CEO to junior, share two related characteristics, both related to learning: humility and respect.

4. Manos and Vincent (2012): Sum total of all the lean tools, techniques and knowledge that exist within an organization at the root level and that fuel the overall organizational alignment via collective lean thoughts, words and actions toward the elimination of waste and the creation of value.

5. Schipper and Swets (2012): An idea that is created in the mind, as an inference, consisting of the collective behaviors, practices and habits of a community of people implementing a lean system.

6. Syed Ahmad (2013): A culture where all employee participating in activities to reduce business waste.

7. Lotz and Roodt (2014): Characterized by a deep respect for people, teamwork and continuous improvement.

8. Novac and Mihalcea (2014): We think at problem solving with continuous improvement and learning.

9. Ulhassan (2014): Everyone seeks improvement, understands value and strives to attain it, and identifies waste and struggles to eliminate it.

10. Charron et al. (2014): Beliefs and behavior characteristics of employees that understand what their company's goals and objectives are, why they are important, understand the purposes of lean improvements, have had the necessary lean tools and techniques training to effect improvements, and are then given a reasonably free hand to do so on an ongoing basis.

11. Salah and Sayed (2015): Organizational environment in which the values and behaviors are aligned with the guiding principles of lean management.

12. Gaudet and Bergeron (2016): Shared language, values and practices of scientifically improving work, every day.

13. Alston (2017): A culture that has all of the elements and attributes required to implement and sustain lean process improvement initiatives. 